\title{
NUCLEAR MAGNETIC RESONANCE STUDIES OF JUNCTIONAL TRANSMITTER-REGEPTOR INTERACTIONS
}

\author{
G. KATO, PH.D.*
}

IT Is GENERALLY BELIEved that acetylcholine ( $\mathrm{ACh}$ ) produces its effect by combining with specific "receptor" substances located in the post-synaptic membrane. This reaction triggers a change in permeability to ions in the post-synaptic cell and destruction of $\mathrm{ACh}$ by a specific enzyme, acetylcholinesterase ( $\mathrm{AChE}$ ). While purified preparations of AChE are available, the second component, a receptor, has not been isolated as yet. Earlier attempts to isolate the receptor substance were largely unsuccessful. ${ }^{1-7}$ None of the three types of macromolecules isolated could be accepted as the $\mathrm{ACh}$ receptor. ${ }^{8} \mathrm{~A}$ basic difficulty in these experiments was the absence of a suitable assay.

The binding of smaller molecules to macromolecular structures can be studied by nuclear magnetic resonance (NMR) spectroscopy. We have used this technique to investigate the protein binding of $\mathrm{ACh}$, and the effects of several blocking and anaesthetic agents.

\section{METHODS}

The following tissues were used: skeletal muscle from cat and frog, rat diaphragm, cat and frog sciatic nerve, and dogs' dorsal and ventral roots.

The protein extract of all tissues was prepared in the following way. The tissue was excised within two minutes after death, frozen on dry ice, and stored at $-30^{\circ}$. About $20 \mathrm{gm}$. of tissue was diced, homogenized in a Sorvall blender with phosphate-buffered saline ( $0.02 M$ sodium phosphate, $\mathrm{pH} 7.5,0.1 \mathrm{M}$ sodium chloride) and centrifuged at $12,000 \mathrm{~g}$ for 90 minutes at $-8^{\circ}$. The supernatant was decanted, and the residue resuspended by homogenization in a small volume of buffer. The combined supernatant was dialysed against phosphate-buffered saline for 24 hours and centrifuged at $12,000 \mathrm{~g}$ for 30 minutes. To about $100 \mathrm{ml}$. of extract at $4^{\circ}$, solid $\left(\mathrm{NH}_{4}\right)_{2} \mathrm{SO}_{4}$ was slowly added with rapid stirring to 100 per cent saturation. The precipitate was collected by centrifugation as before and dissolved in about $20 \mathrm{ml}$. phosphate-buffered saline $(0.02 \mathrm{M}$ sodium phosphate, pH 7.5, $0.1 M$ sodium chloride). After removing a small amount of insoluble material by centrifugation, the supernatant was dialysed against distilled water for 48 hours.

The extract was centrifuged as before to remove undissolved particles and lyophilized to dryness.

For the NMR measurements, the samples were prepared by dissolving $\mathrm{AChCl}$ (Hoffmann-La Roche) and the protein or horse serum ChE (Sigma) in a $\mathrm{D}_{2} \mathrm{O}$ (Columbia) sodium phosphate buffer $(0.2 M, \mathrm{pH} 7.4)$. Drug concentrations ( $M$ )

"Wellcome Department of Research in Anaesthesia, McGill University, Montreal. Supported by the Canadian Medical Research Council. 
were all expressed in moles/L., and protein concentrations as a percentage (weight/ volume). The solutions were placed in standard $5 \mathrm{~mm}$. NMR tubes. Chemical shifts are expressed in c.p.s. from tetramethylsilane (TMs) as an external standard. All measurements were made on a Varian Associates A-60 NMR spectrometer with temperature control accessories. Measured line-widths were corrected for instrumental line-width and values of the relaxation rate $1 / T_{2}$ were calculated from the spectral line-widths using the formula

$$
1 / T_{2}=\pi \Delta V_{1 / 2}
$$

where $\Delta V_{1 / 2}$ is the line-width at one-half maximum peak height.

\section{REsults}

Jardetzky and his colleagues ${ }^{9,10}$ have shown that, by measurement of proton magnetic relaxation, it is possible to observe a differential rotational stabilization of certain protons in complexed small molecules. This selective broadening of the spectral peaks (corresponding to an increase in relaxation rate) was interpreted as a specific interaction involving the corresponding chemical groups. From the broadening of the line-width it is therefore possible to deduce the degree of binding.

The NMR spectrum of $0.1 \mathrm{MAChCl}$ in $\mathrm{D}_{2} \mathrm{O}$ phosphate buffer $(0.2 \mathrm{M}, \mathrm{pH} 7.4)$ is shown in Figure 1a. The spectrum consists of peaks (1) which are due to the four hydrogens on $C_{4}$ and $C_{5}$. The quaternary ammonium group (2) is identified by a singlet at 195 c.p.s. downfield from the reference point (TMs). Peak 3 is due to the acetate protons in ACh. Measurement of line-width will be confined to the two single peaks 2 and 3. Figure lb shows the effect of "receptor" protein (from isolated frog muscle) on the line-width of ACh. Both peaks 2 and 3 are broadened but not to the same extent. This interaction takes place in $\mathrm{D}_{2} \mathrm{O}$ buffer solution and depends on such factors as $\mathrm{pH}$, concentration of reactants, time, temperature, and the presence or absence of inhibitors. At $36^{\circ}$, and two minutes after mixing the reagents, the relaxation rate of the quaternary ammonium peaks of an $0.1 \mathrm{M}$ $\mathrm{AChCl}$ solution increases by a factor of 5.2 , whereas that of the acetate protons increases by a factor of 4 when the 10 per cent protein is added. It appears then that the quaternary ammonium "head" is preferentially stabilized by the interaction of ACh and "receptor" protein and that this group is the primary binding site. The relaxation rate for both peaks 2 and 3 of $\mathrm{ACh}$ in the presence of the isolated protein depends not only on the protein concentration but on the AChprotein ratio. Increasing the $\mathrm{ACh}$ concentration from $0.05 \mathrm{M}$ to $1.5 \mathrm{M}$ reduces the relaxation rates of both quaternary ammonium and acetate protons in the presence of 10 per cent protein.

Figure 1. (a) NMr spectrum of $0.1 \mathrm{M} \mathrm{AChCl}$ in $\mathrm{D}_{2} \mathrm{O}$ phosphate buffer $(0.2 \mathrm{M}$, pH 7.4). Shifts are from tetramethylsilane as an extemal standard. Peaks labelled $I$ are due to the four hydrogens on $\mathrm{C}_{4}$ and $\mathrm{C}_{5}$. Peak 2 is the quaternary ammonium group, and peak 3 is the acetate group of ACh. (b) NMR spectrum of $0.1 \mathrm{MAChCl}$ in the presence of 8 per cent "receptor" protein in $\mathrm{D}_{2} \mathrm{O}$ phosphate buffer $(0.2 \mathrm{M}, \mathrm{pH} 7.4)$; temperature $36^{\circ}$. 


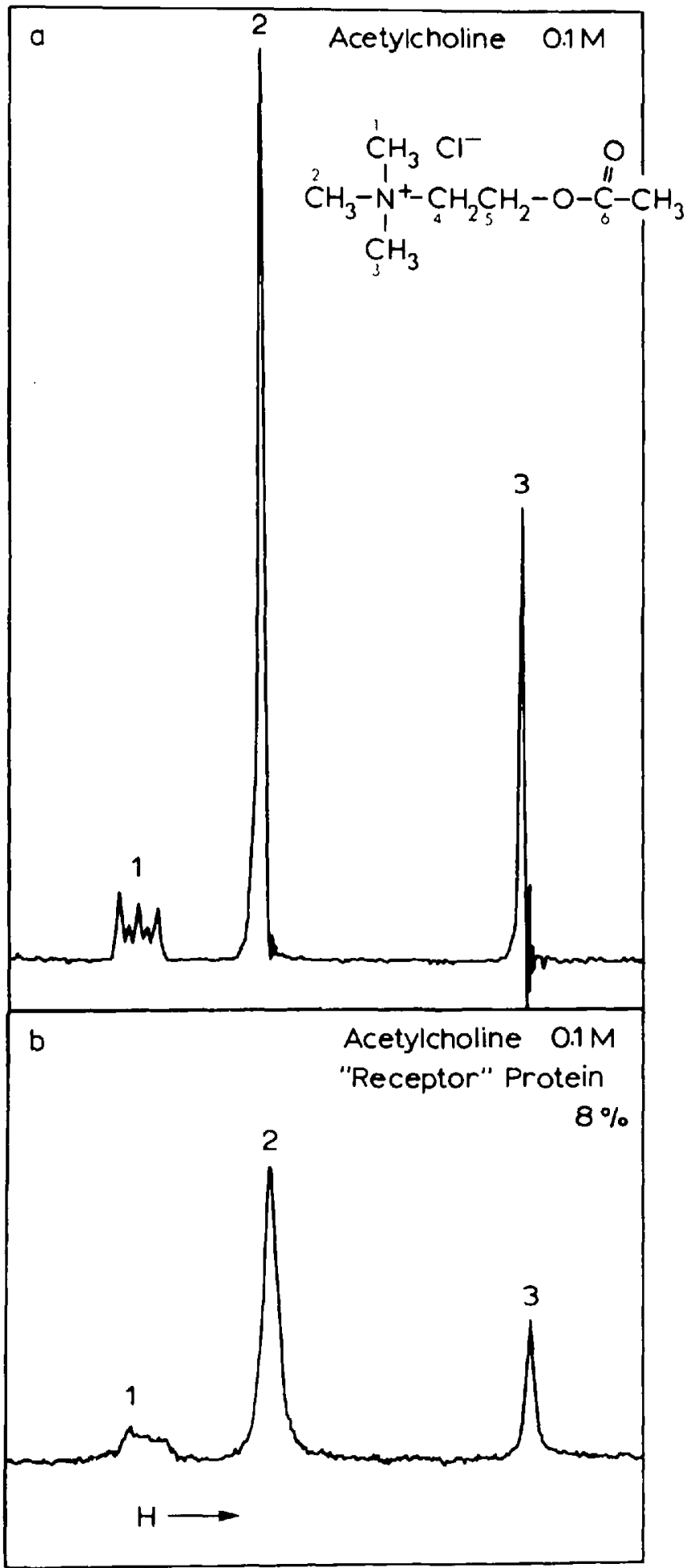


Other isolated proteins also have a marked effect on the broadening of the spectral peaks of ACh. In a descending order of binding capacity, the proteins from frog sciatic nerve, ventral roots of dogs, and rat diaphragms bind strongly to the quaternary ammonium group of $\mathrm{ACh}$, whereas proteins from dorsal roots of dog do not. The effect of $5 \mathrm{~m} M$ d-tubocurarine (d-t) was to prevent the binding of $0.1 \mathrm{M} \mathrm{ACh}$ to sciatic nerve, frog skeletal muscle, and rat diaphragm extracts. That the observable increases in relaxation rates were not produced by changes in viscosity or by drug-drug interaction was shown by the fact that $(a)$ the viscosity of the protein solutions never exceeded twice the viscosity of pure $\mathrm{D}_{2} \mathrm{O}$-this could not account for the observed effects; $(b)$ lowering the temperature reduced stabilization of both peaks of $\mathrm{ACh}$ in the presence of 10 per cent protein; and $(c)$ increasing the $\mathrm{ACh}$ concentration alone (without added protein) in a phosphate buffered $\mathrm{D}_{2} \mathrm{O}$ solution $(0.2 \mathrm{M}, \mathrm{pH} 7.4)$ from 0.05 to $2 M$ only increased the relaxation rate of peak 2 by a factor of 1.05 .

The interaction between ACh and these macromolecules, however, does not depend on a prolonged interaction or binding. Systematic studies on the time course of the reaction between $A C h$ and receptor protein (frog muscle) at various temperatures indicates that the ACh-protein interaction is quite transient. These results-partly shown in Figure 2-indicate that maximum binding occurs at $36^{\circ}$, and at 80 seconds from the time of mixing for the acetate peak and at 120 seconds for the quaternary ammonium peak. The binding of both groups of $\mathrm{ACh}$ to the protein is blocked by $5 \mathrm{mM}$ d-t. These effects were not produced by $\mathrm{ChE}$ activity because no hydrolysis occurred wthin the first 15 minutes of observation. Our studies with purified horse serum ChE have shown that when there is no enzyme hydrolysis, there is also no binding between $\mathrm{ACh}$ and $\mathrm{ChE}$. The rate of binding between $0.1 \mathrm{MACh}$ and a 10 per cent solution of purified horse serum $\mathrm{ChE}$ is shown in Figure 3. The broadening of the quaternary ammonium peak in the case of $\mathrm{ChE}$ reaches a maximum after six minutes and then decays exponentially. Maximum binding between $\mathrm{ACh}$ and $\mathrm{ChE}$ occurs progressively later with decreasing enzyme concentration.

The initial binding of the quaternary ammonium and acetate groups of $\mathrm{ACh}$ by $\mathrm{ChE}$, as well as the enzymatic hydrolysis, is blocked by $0.05 \mathrm{M}$ eserine, neostigmine, tensilon, xylocaine, and procaine. Ether and halothane had little or no effect. With nembutal $(0.02 M)$ the maximum binding rate between ACh and ChE was accelerated and there was a concomitant potentiation of the rate of hydrolysis of $\mathrm{ACh}$. The above-mentioned inhibitors are more strongly bound to the enzyme than is $\mathrm{ACh}$.

\section{Discussion}

A number of attempts have been made in the past to isolate and identify the ACh receptor in solution. Chagas and coworkers ${ }^{1-3}$ have reported that a hyaluronic acid type of molecule was the receptor on the basis of its ability to react with the neuromuscular blocking agent, gallamine triethiodide. Their experiments, however, are invalid because their binding studies, using dialysis techniques, were performed in distilled water. Under physiological conditions of $\mathrm{pH}$ and ionic strength, they failed to observe binding with d-t. Ehrenpreis ${ }^{4-6}$ isolated a 


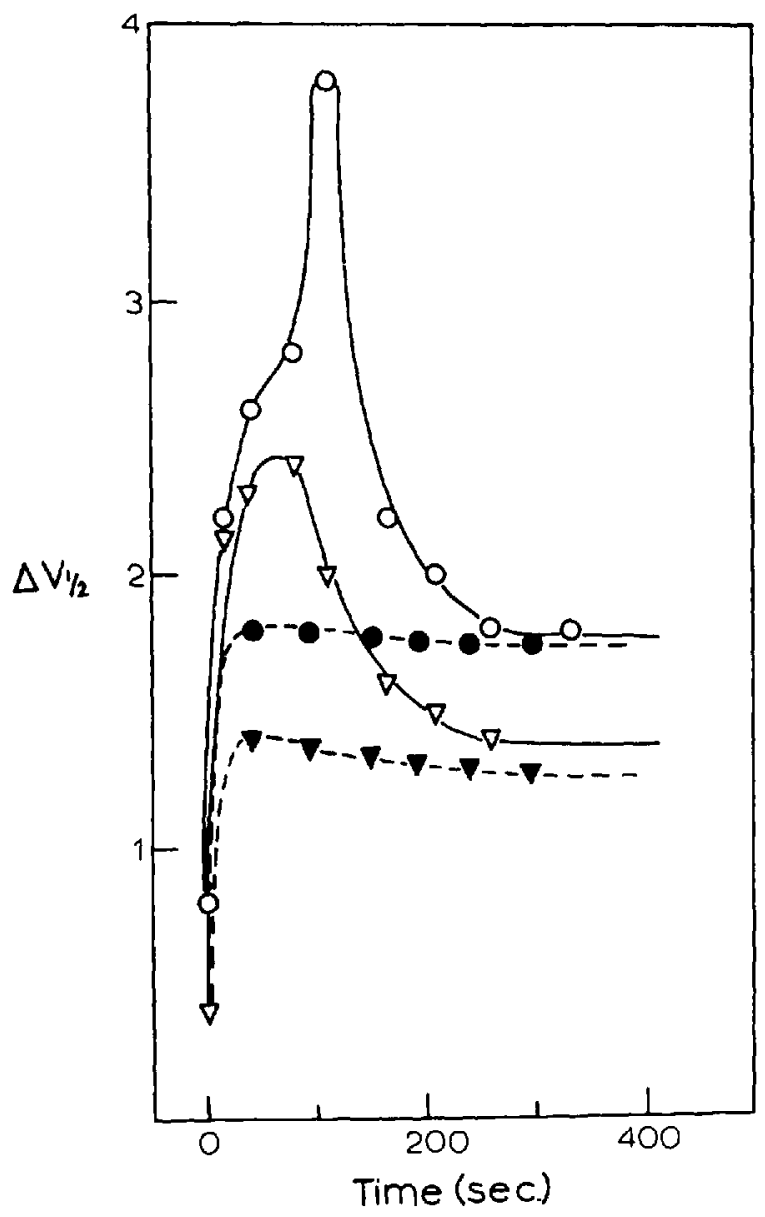

FIGURE 2. Change in line-width ( $\triangle V_{1 / 2}$ c.p.s.) of $A C h$ in the presence of 8 per cent "receptor" protein. $\mathrm{O}$ $\left(\mathrm{CH}_{3}\right)_{3} \mathrm{~N}$ protons; $\nabla$-acetate protons. At zero time 0.1 $M \mathrm{AChCl}$ was mixed with an 8 per cent "receptor" protein solution in $\mathrm{D}_{2} \mathrm{O}$ phosphate buffer $(0.2 M, \mathrm{pH} 7.4$, $\left.36^{\circ}\right)$. $-\left(\mathrm{CH}_{3}\right)_{3} \mathrm{~N}$ protons, and $\nabla$-acetate protons, in the presence of $5 \mathrm{mM}$ d-t.

"receptor" protein from fish electric organ (innervated by cholinergic fibres) by precipitating a protein extract with d-t. His claims, however, have been proven erroneous by the work of Beychok ${ }^{11}$ and others. ${ }^{8}$ Grob and Namba ${ }^{7}$ have also used $\mathrm{d}-\mathrm{t}$ to precipitate the postulated receptor from a skeletal muscle extract. It is well known, however, that $\mathrm{d}$-t binds many substances in a non-specific way and therefore is of relatively little value in identifying the $\mathrm{ACh}$ receptor. Thus the ability to combine strongly with an ACh antagonist is not sufficient for the identification of the $\mathrm{ACh}$ receptor. The apparent failure of isolation may thus be attributed to the absence of a suitable assay procedure.

The understanding of the properties of the receptor depends on the use of a 


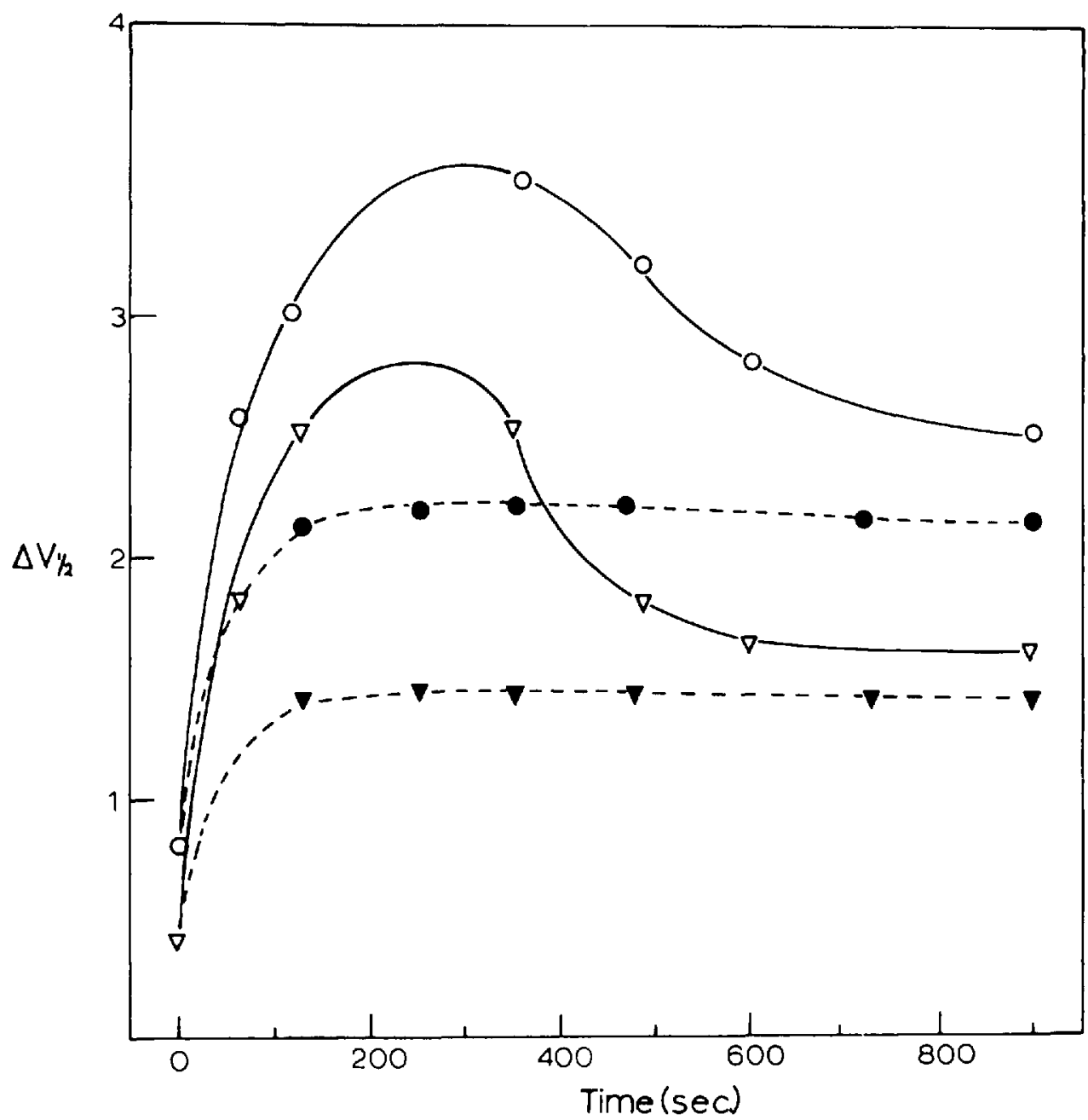

Figure 3. Change in line-width ( $\triangle V_{1} /$ c.p.s.) of $\mathrm{ACh}$ in the presence of 10 per cent $\mathrm{ChE}$ (horse serum). $\mathrm{O}-\left(\mathrm{CH}_{\mathrm{a}}\right)_{\mathrm{a}} \mathrm{N}$ protons; $\nabla-$ acetate protons. At zero time $0.1 \mathrm{M} \mathrm{AChCl}$ was mixed with a 10 per cent $\mathrm{ChE}$ solution in $\mathrm{D}_{2} \mathrm{O}$ phosphate buffer $\left(0.2 \mathrm{M}\right.$, pH $\left.7.4,40^{\circ}\right)$. $-\left(\mathrm{CH}_{3}\right)_{3} \mathrm{~N}$ protons, and $\nabla$-acetate protons, in the presence of $0.05 \mathrm{M}$ eserine sulphate.

reliable method for the study of the protein-ACh binding in solution. We have shown that nuclear magnetic resonance spectroscopy can be used to test the existence and examine the nature of $\mathrm{ACh}$-receptor interactions.

On the basis of our studies, it is apparent that there exists a strong binding between ACh and the isolated "receptor" protein. The negative group on the protein, referred to as the "anionic site," attracts the quaternary nitrogen group of ACh by Coulombic or van der Waals' forces. Another site, referred to as the "esteratic site" in $\mathrm{ChE}$, also plays an essential role in the ACh receptor. Its function is to bind the acetate group of ACh presumably by similar forces (see Fig. 4). Figure 2 shows that the reaction between receptor and substrate in vitro is limited to a transient interaction having a duration of approximately three 


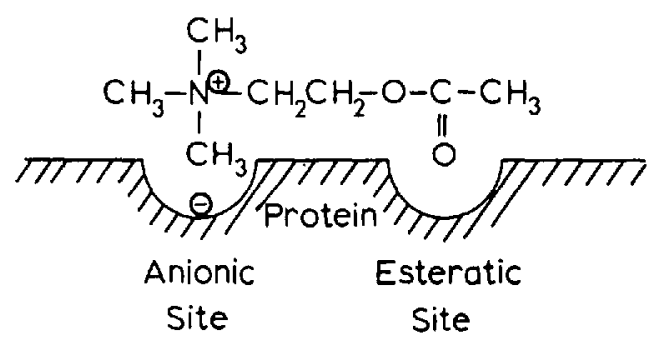

FIGURE 4. Schematic presentation of the active surface of "receptor" protein.

minutes. One is tempted to deduce from our observations that the acetate site serves as an "anchor" for an initial interaction followed by a more pronounced interaction between the quaternary ammonium groups and the anionic receptor site on the protein. This is followed by the subsequent release of $\mathrm{ACh}$ into the surrounding medium. These findings are consistent with the physiological concept that the ACh-membrane interaction is quite transient. The time course between $\mathrm{ACh}$ and receptor in situ, however, appears to be much shorter (of the order of a few milliseconds).

We have also shown that the effect of $d-t$ is to prevent the binding between $\mathrm{ACh}$ and the isolated macromolecule. Further experiments in our laboratory indicate that d-t has a greater affinity for the isolated protein than has ACh. It is evident, then, that d-t is more strongly attracted to the macromolecule than $A C h$, and its effect is to prevent the binding of $\mathrm{ACh}$ to the receptor sites.

There is reason to believe that this protein fraction isolated from frog skeletal muscle is heterogeneous, although our results indicate that there are ACh receptors present. The protein isolated from skeletal muscle of other species showed similar binding properties when mixed with $\mathrm{ACh}$. The possibility that the observed effects were due to $\mathrm{ChE}$ was eliminated by the fact that no hydrolysis of $\mathrm{ACh}$ occurred during the time in which the readings were taken. We have shown that if no hydrolysis occurs, no binding occurs between $\mathrm{ACh}$ and $\mathrm{ChE}$. As compared with "receptor" protein, $\mathrm{ChE}$ gives a greater increase in the stabilization for the acetate group of $\mathrm{ACh}$ than for the quaternary ammonium group. This is not surprising, after all, since the function of the enzyme is to hydrolyse the acetate group; for optimal enzyme-substrate interaction strong binding would be essential.

Present investigations in our laboratory are concerned with the purification of our protein extract in order to isolate and identify receptor molecules.

\section{SUMMARY}

The technique of nuclear magnetic resonance spectroscopy was used to study the interaction between $\mathrm{ACh}$ and cholinesterase or muscle "receptor" protein. With a pure solution of $\mathrm{ACh}$, the nuclear magnetic resonance occurs over a narrow region of magnetic field and therefore sharp absorption bands are observed. As molecular motion decreases, the absorption bands are broadened. 
From the broadening of the observed lines it is possible to deduce the degree of binding.

By extraction with phosphate buffer, a protein was isolated from skeletal muscle which binds acetylcholine. The NMR spectrum of a solution of $\mathrm{AChCl}$ in $\mathrm{D}_{2} \mathrm{O}$ consists of three major peaks, the first of which is attributed to the four protons attached to the carbon skeleton, and the other two to the methyl groups on the quaternary nitrogen and the methyl groups of the acetate radical. Upon addition of "receptor" protein, a selective broadening of the ACh spectral peaks is observed. This binding between ACh and protein is transient and is prevented by d-tubocurarine. The transient nature of the ACh-receptor interaction is consistent with a physiological action of $\mathrm{ACh}$ at the receptor site. The interaction is a two-point stabilization of the $\mathrm{ACh}$ molecule and is independent of cholinesterase sites. Addition of $\mathrm{ChE}$ to $\mathrm{ACh}$ solutions also causes a marked broadening of the ACh spectral peaks. The broadening of the quaternary ammonium peak reaches a maximum after ten minutes and it then decays exponentially. The initial binding of the quaternary ammonium and acetate groups of ACh by ChE, as well as the enzymatic hydrolysis of $\mathrm{ACh}$, is blocked by $\mathrm{ChE}$ inhibitors and by local anaesthetics. Volatile anaesthetics had little or no effect. With nembutal, the maximum binding rate between $\mathrm{ACh}$ and $\mathrm{ChE}$ was accelerated and there was a concomitant potentiation of the rate of hyrolysis of $\mathrm{ACh}$.

\section{RÉSUMÉ}

La technique de spectroscopie de résonance magnétique nucléaire a été utilisée pour étudier l'interaction entre l'ACh et la cholinestérase ou la protéine réceptriée du muscle. Si l'on utilise une solution pure d'ACh, la résonance magnétique nucléaire survient dans une région étroite du champ magnétique et on observe alors des bandes d'absorption prononcées. A mesure que l'activité moléculaire diminue, les bandes d'absorption s'élargissent. A l'élargissement des lignes observées, l'on peut déduire le degré de liaisons.

Par extraction à l'aide d'un phosphate tampon, l'on a isolé, des muscles squelettiques, une protéine qui peut lier l'acétylcholine.

Le spectre NMR d'une solution de $\mathrm{AChCl}$ dans $\mathrm{D}_{2} \mathrm{O}$ consiste en trois principales élévations : la première attribuée aux quatre protons attachés au squelette de carbone, et les deux autres aux groupes méthyles sur l'azote quaternaire et les groupes méthyles du radical acétate. Si l'on ajoute la protéine réceptrice, il apparait un élargissement sélectif des élévations spectrales de l'ACh. Cette liaison entre l'ACh et la protéine est temporaire et elle est inhibée par la d-tubocurarine.

La nature transitoire de l'intéraction $\mathrm{ACh}$ et son récepteur concorde avec l'action physiologique de l'ACh au niveau du récepteur. L'interaction est une stabilisation à deux endroit de la molécule d'ACh et elle est indépendante des sites de la cholinestérase. L'addition de ChE aux solutions d'ACh cause également un élargissement marqué des élévations spectrales de l'ACh. L'élargissement de l'élévation de l'ammonium quaternaire atteint un maximum après dix minutes et, alors, décroit de façon exponentielle. La liaison initiale de l'ammonium quaternaire et des groupes acétate de $\mathrm{ACh}$ par $\mathrm{ChE}$ aussi bien que l'hydrolyse enzymatique 
de l'ACh sont bloquées par des inhibiteurs ChE et par les anesthésiques locaux. Les agents anesthésiques volatiles n'ont que peu ou pas d'effet. Avec le nembutal, le taux de liaison maximum entre l'ACh et ChE était accéléré et, concommittamment, l'on observait une potentiation du taux d'hydrolyse de l'ACh.

\section{REFERENCES}

1. Chagas, C. The Fate of Curare During Curarization. Ciba Foundation Study Group, no. 12, Curare and Curare-like Agents, 2. London: Churchill (1962).

2. Chagas, C.; Penna-Franca, E.; Nishe, K.; \& Garcia, E. J. A Study of the Specificity of the Complex Formed by Gallamine Triethiodide with a Macromolecular Constituent of the Electric Organ. Arch. Biochem. Biophys. 75: 251 (1958).

3. Chacas, C. Studies on the Mechanism of Curarization. Ann. N.Y. Acad. Sc. 81: 345 (1959).

4. Ehrenpreis, S. Isolation and Identification of the Acetylcholine Receptor Protein of Electric Tissue. Biochim. Biophys. Acta 44: 561 (1960).

5. - - The Isolation and Identification of the Acetylcholine Receptor from Electric Tissue of Electrophorus electricus. In: Bioelectrogenesis. C. Chagas \& A. P. de Carvalho, eds. Amsterdam: Elsevier (1961), p. 379.

6. - - Interaction of Curare with an Acetylcholine Receptor-like Protein. Fed. Proc. 18: $220(1959)$.

7. Grob, D. \& NAMBA, T. In Vitro Reaction of Human Skeletal Muscle with Neuromuscular Agents. Fed. Proc. 22: 215 (1963); Immunologic Evidence for Identification of Muscle Receptor Protein. Fed. Proc. 23: 310 (1964); Cholinergic Receptors in Skeletal Muscle. Ann. N.Y. Acad. Sc. 144: 772 (1967).

8. Ehrenpreis, S. Possible Nature of the Cholinergic Receptor. Ann. N.Y. Acad. Sc. 144: 720 (1967).

9. Fischer, J. J. \& JAFDETZKY, J. 1965. Nuclear Magnetic Relaxation Study of Intermolecular Complexes: The Mechanism of Penicillin Binding to Serum Albumin. J. Am. Chem. Soc. 87: 3237 (1965).

10. JARDETzKY, O. \& WADE-JARDETzKY, N. G. On the Mechanism of the Binding of Sulfonamides to Bovine Serum Albumin. Mol. Pharmacol. 1: 214 (1966).

11. Beycror, S. On the Problem of Isolation of the Specific Acetylcholine Receptor. Biochem. Pharmacol. 14: 1249 (1967). 